\title{
Microbiotechnological Stimulation of the Root Systems of Woody Plants within the Scope of the Revitalization of Mining Works
}

\author{
Miloslav Šoch1, Bohuslav Vostoupal', Jaroslava Vráblíková2, Petr Vráblík², Jana Št'astná1 \\ ${ }^{1}$ Faculty of Agriculture, University of South Bohemia in České Budějovice, České Budějovice, Czech Republic \\ ${ }^{2}$ Faculty of Environmental Science, Jan Evangelista Purkyně University in Ústí nad Labem, Ústí nad Labem, Czech Republic \\ Email: soch@zf.jcu.cz, petr.vrablik@ujep.cz
}

How to cite this paper: Šoch, M., Vostoupal, B., Vráblíková, J., Vráblík, P. and Štastná, J. (2018) Microbiotechnological Stimulation of the Root Systems of Woody Plants within the Scope of the Revitalization of Mining Works. Agricultural Sciences, 9, 1529-1537.

\section{https://doi.org/10.4236/as.2018.912107}

Received: October 31, 2018

Accepted: December 2, 2018

Published: December 5, 2018

Copyright $\odot 2018$ by authors and Scientific Research Publishing Inc. This work is licensed under the Creative Commons Attribution International License (CC BY 4.0).

http://creativecommons.org/licenses/by/4.0/

\begin{abstract}
In general, the conditions for the growth of vegetation in former mining works are unfavorable, particularly in locations where the rooting process or inadequate functional contact by the root system with underground water, creates vegetative problems. For the process of the revitalization of the disrupted areas to be successful, the correct rooting of woody plants is essential for starting the development of the vegetation, and directing it towards greater biodiversity. The addition of bio alginates, whose basic raw component is selected seaweed, to the soil ensures the stimulation of the root system, thereby significantly increasing the likelihood of the plants surviving. The article monitors, in detail, the effect of the application of these bio alginates, and the subsequent response of the plants in growth patterns.
\end{abstract}

\section{Keywords}

Bioalginates, Soil, Root System, Abandoned Mining Works, Reclamation

\section{Introduction}

The quality of plant tissues and their healthy tissular turgor, just like the richness of the branching of the root system, belongs among the physiological indicators of the plant's full potential, its perfect vitality and, last but not least, also its targeted yield. In this specific case, it is also a sign of a full functional yield, relating to rehabilitation, technical and possibly also power-producing plants, and last but not least also to plants which function as an active component of so-called root purifiers.

A no less important fact is that, in additional to a nutritional function, root 
systems also have a secondary, fixation function. This is mainly during the reinforcement of the terrain, as an effective anti-erosion and also anti-abrasion mass, particularly on sloping sections and on the collateral surfaces of terrain furrows on road and railway routes, as well as on the terraces of mine dumps etc. Bio alginates are agents which significantly strengthen these functional dispositions, without negatively burdening or contaminating the environment in any way. This is because they are completely consumed by the perceptive sphere of soil microbiota, and in the process of their metabolization they are converted mainly into a high level of easily accessible vital energy.

The raw material for the production of bio alginates is specially mined, dried and finally hydrolyzed selected seaweed, which is present in the shallow and clean coastal waters of arctic seas in the area of Iceland and other Scandinavian countries, as well as in coastal areas of Canada [1] [2] [3] [4]. It is purposefully harvested in these areas using special techniques, and then treated, dried and preserved for further use [5] [6] [7]. It finds successful application in the form of specially formulated seaweed preparations, not only in rehabilitation, redevelopment, revitalization and agricultural fields [1] [8] [9] [10] [11], but also in other biological areas (food supplements, surgery, dermatology, gynecology etc. [12]). It offers its own participation in the traditional sphere of the rehabilitation of plants and plant communities, particularly in areas with an unfavorable soil environment burden [7] [13] [14], but also while increasing the value of biological waste materials and the specific preservation of catabolites during the biodegradation of spontaneously released nutrients [1] [3] [10] [11] [12] [15] [16]. Bio alginates also possess a strong and wide-spectrum detoxification capability, which is also applied in the soil profile or in the deposited layers of waste materials of a biological origin [1] [12] [17] [18].

The article proved positive influence of bio alginates that were applied on caryopsis if winter and spring wheat in time of columning. All of the monitored indicators showed positive response on bio alginates, especially root volume of spring wheat, where the difference between treated and non-treated samples indicated increase in root volume for over $13 \mathrm{ml}$. Second part of the research was an experiment for observation of one-off effect of bio alginates applied to pots with summer oak seedlings, where soil from spoil tips was used as a growth medium.

\section{Materials and Methods}

Preparations from the bio alginate range are a concentrate of specific plant gels and natural polysaccharides, composed primarily of polyuronic seaweed acids. These uronic acids are polyelectrolytes, with a high ion exchange capacity at a level of 5000 - 20,000 m/val. [1] [12] [15]. They absorb substances released by the biological decomposition of organic matter, as well as an entire range of toxic elements and components [9] [14] [19]. Their molecular structure is identical to gray humic acid which, together with fine soil particles, is able to create a 
clay-humus complex [11] [14]. They create complexes with heavy metals, and eliminating their toxicity [10]. In water, bio alginates form-under the influence of metals-a water-insoluble "gel-flake" system, which successfully eradicates the current toxicity of these metallic elements. The given example actually involves a multi-functional and universal nutritious soil, in whose presence cooperative decomposition microorganisms multiply very quickly and in a balanced manner, without being affected by disruptive chemical factors [7] [9] [11] [17] [20].

The equipping of these seaweed hydrolyzates with specific phytohormones and a wide additional spectrum of biologically effective substances determines their ability to significantly stimulate the processes of the multiplication and growth of root systems, as well as the development of supporting microbial communities [1] [2] [21].

One of the effective methods that were used for the experiment is the application of bio alginate preparations. These preparations work spontaneously even during simple application, e.g. during planting, particularly during planting in an environment about whose vegetative dispositions we have justified doubts. Past experience confirms that the most suitable application method during rehabilitative planting so far, particularly of bare-root seedlings, is the thorough immersion of the entire seedling in the prepared bio alginate bath (1 part Bio-algeen [B.A] root concentrate: 8 parts utility water). After covering it with soil-particularly in unfavorable soil-climatic conditions-the set plant should also be supplied with a dose of 1 spoon of B.A. Granulate.

The reason for the immersion of the entire seedling is based on the specific properties and functional biochemistry of the bio alginate structure. With their protective film, formed in this way from their solution on the surface of plant tissues, effectively prevents the excessive evaporation of water from the seedling organism. It does so both immediately during and shortly after planting (solar radiation, if applicable high temperature and low relative humidity of the surrounding air) and particularly in the critical period of their adaptation to a new environment.

The aforementioned protective film from bio alginates forms semi-permeable membranes on the plant's surface areas, which allow the intake of water into the plant but prevent its loss from it. Specific B.A. formulation The granulate also has another positive property, consisting of the fact that it is able to bind as many as 350 parts by weight of water to itself-it therefore forms an important and relatively extensive life-saving and hydrating focal deposit in the root environment.

Thanks to this collective anti-stress mechanism, supplemented by the significant buffering capacity of bio alginates, the shock of the replanted vegetation due to the change of environment is reliably minimized. Moreover, bio alginatesthanks to their biostimulative properties-support and accelerate the settlement and development of mycorrhizal root communities and other soil-based microbial cooperators. However, they can also be used as a sufficient substitution for 
vegetation, in the form of directed watering or a pressurized injection into the soil, into the area of the expected root branching.

Apart from the fact that bio alginates induce and subsequently support the development of a stronger root system, in this way they also stimulate the plant to increase its fertility. Of significance is also the verified fact that bio alginatesor the consequences thereof-are effective in the soil for 1 - 3 years. A basic principle of the utilization of bio alginates during managed and rehabilitative plant cultivation is the stimulation of their growth using a concentrate of polyuronic acids, amino acids, phytohormones and trace elements, contained in used products with bio alginate component content. These effective substances affect all green plants in general, by accelerating and intensifying their life functions, and increasing photosynthesis and substance exchange. At the same time, the plants develop harmoniously, and fully utilize their genetic potential. The natural form of support for the development of the root system is also closely linked to the development of a stronger and healthier aboveground part (Figure 1 and Figure 2).

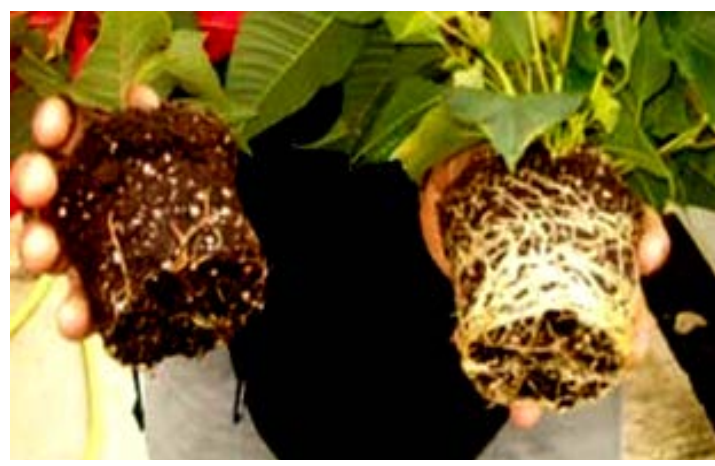

Figure 1. Model illustration of the effect of bio alginates on the development of the root systems of potted plants (plants of the same type and origin, planted in identical soil and cultivated under exactly the same conditions). They differ only in that the plant on the left was watered with clean water, while water with bio alginate content was used on the plant on the right. The differences in the richness of the root stitching are clearly evident (the producer's photograph was used).

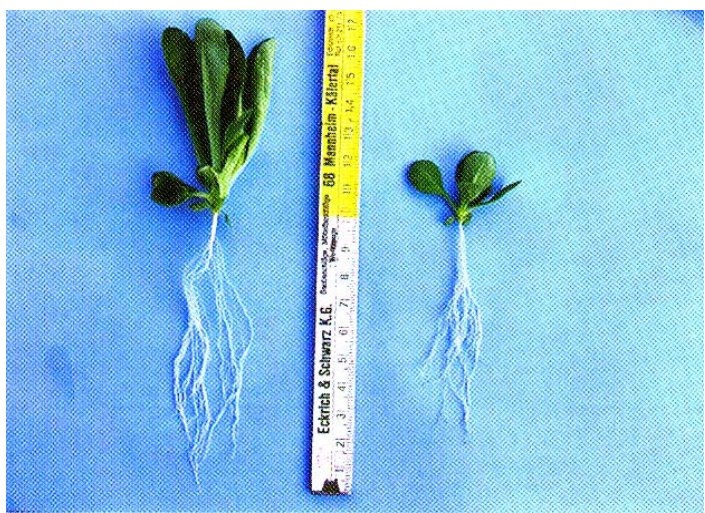

Figure 2. Comparative presentation of two young experimental plants-on the left: growing under the effect of bio alginates and on the right: without their effect (the producer's company materials were used). 
The effect of the application of bio alginates, primarily on the root system and subsequently on the above-ground part of the plant, is also clearly evident in Figure 3.

\section{Results and Discussion}

Results of a comparative experiment monitoring the effect of the application of bio alginate on caryopsis, and its response in certain growth patterns are shown in Table 1. The observed species of plant were winter and spring wheat at time of columning. Within the monitored values (root volume, aboveground part dry matter, dry root matter) positive effects of bio alginates were observed on both species of wheat. The most significant change was increase in all of the monitored indicators in case of spring wheat, especially the increase of root volume of the sample treated with bio alginate (Table 1).

Second experiment to demonstrate positive effects of bio alginates was a

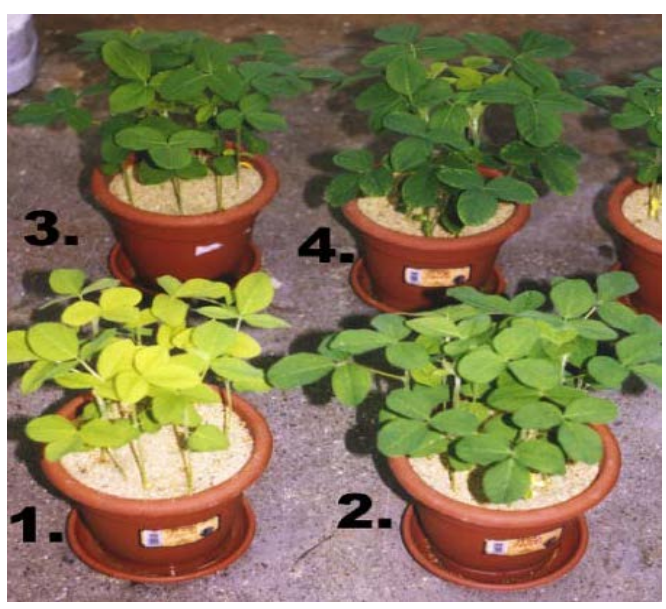

Figure 3. Demonstrative effect of the application of bio alginates during the replanting of vegetation. Experimental container no. 1 was not treated with bio alginates at all. Container no. 2 was only treated by one-time watering with a diluted B.A. preparation. In the case of container no. 3 , the watering was combined with the application of B.A. root concentrate, while container no. 4 presents the effect of the application of watering with a root concentrate and the application of B.A. granulate to the soil substrate (the producer's company materials were used).

Table 1. Comparative expression of the effect of the addition of B.A. Bio alginate S-90 on both aboveground and underground development-root sections of the model plant.

\begin{tabular}{|c|c|c|c|c|}
\hline \multicolumn{5}{|c|}{$\begin{array}{l}\text { Results of a comparative experiment monitoring the effect of the application of bio alginate on caryopsis, } \\
\text { and its response in certain growth patterns }\end{array}$} \\
\hline \multirow{2}{*}{ Monitored value indicator } & \multicolumn{2}{|c|}{ Winter wheat at time of columning } & \multicolumn{2}{|c|}{ Spring wheat at time of columning } \\
\hline & Standard no treatment & Treated with bio alginate & Standard no treatment & Treated with bio alginate \\
\hline Root volume [ml] & 8.2 & 16.6 & 9.6 & 22.8 \\
\hline Aboveground part dry matter $[\mathrm{g}]$ & 1.17 & 1.63 & 1.4 & 2.58 \\
\hline Dry root matter $[\mathrm{g}]$ & 0.27 & 0.51 & 0.31 & 0.99 \\
\hline
\end{tabular}


one-time application of the B. A. Granulate into two pots with summer oak seedlings. Soil from spoil tips, created during brown coal mining, was used as a growth medium. This type of soil often shows signs of contamination, and is low on nutrients. In order to accelerate the growth of vegetation (mainly the root system) during reclamation and restoration works on the spoil tips, the application of bio alginates proved to be very effective (Figure 4).

The stimulation of the development of root systems is justified in several respects:

- to achieve the development of higher-quality, healthy and well-rounded plants;

- to achieve a better root connection in the soil and subsequently also better reinforcement of the soil, particularly in sloping positions and inundated territories;

- the presence of bio alginates near the root capillaries also functions similarly to gray humic acid with a buffering dispositions, has a protective effect on developing roots, and coworks as a focal element of the accumulation of soil moisture and on the principle of permanently induced ion exchange;

- in addition to this-as a basic effect-even during one-time treatment, bio alginates show an ability to safely induce a 30 - 50\% growth in the root matter of treated plants or cultures;

- the stimulative and supportive effect of bio alginates during the building and operational management of root water purifiers, whose effectiveness, lifespan and capacity disposition is clearly supported by bio alginates; under the specific conditions of thorough aeration, they also increase their effectiveness during the decontamination of waters by petroleum-based substances.

The results of the experiments proved that application of bio alginates has a

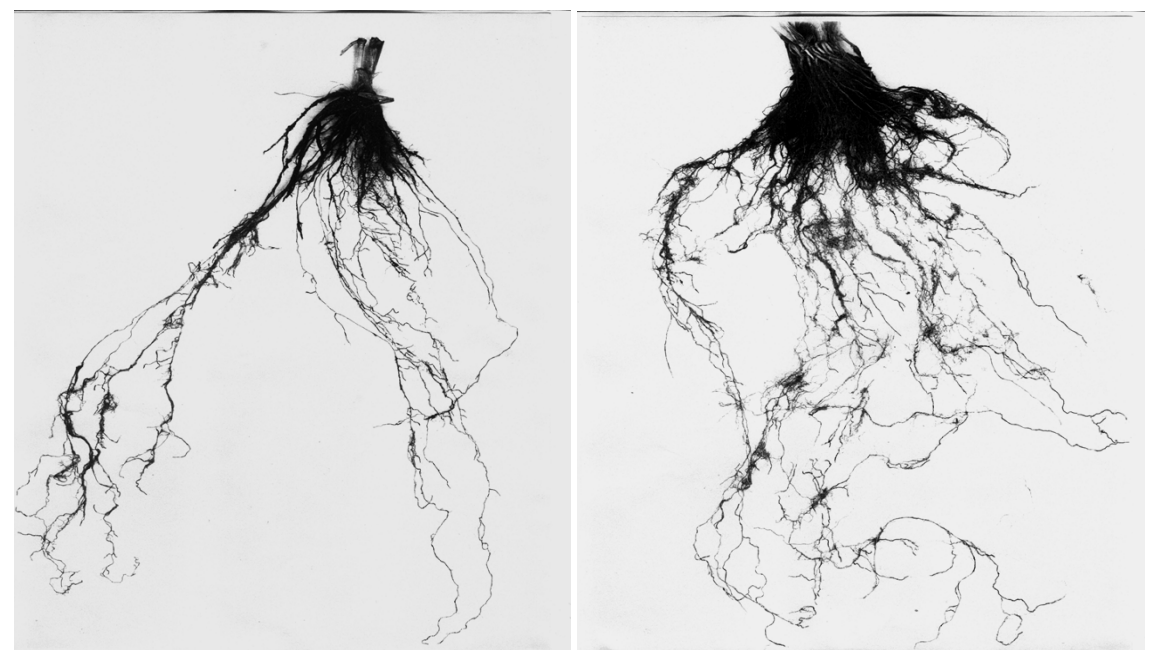

Figure 4. Pictorial presentation of the one-time effect of bio alginates on the development of the root system of the English oak (under the specific conditions of soil from mine dumps), effective only during half of the vegetation period). On the left-root system not affected by bio alginates, on the right-roots developing under the direct effect of a one-time dose of B.A. Granulate. 
positive effect on vegetation in rehabilitation, redevelopment, revitalization and agricultural fields [1] [8] [9] [10] [11], especially when it comes to areas with soils with higher contamination and lower nutrient content [7] [13] [14]. Substrate on the spoil tips that are created during surface brown coal mining are example of such soils. In order to succeed the reclamation of the anthropogenic formations, a good growth medium for vegetation must be ensured. An important function of bio alginates when applied on spoil tip soils is their complex creation with heavy metals, thereby eliminating their toxicity [10]. The application of bio alginates is an effective solution to improve reclamation and restoration processes.

\section{Conclusions}

To conclude the positive effects of bio alginates: They increase the fertility of all soils and substrates, make it accessible to plants and hardly available nutrients, and they regulate water regime, increase erosion and drying resistance, help in the development of soil micro-organisms. They can be active in the soil for 1 - 3 years and ensure faster and healthier growth of planted plants, a more powerful root system, and increased fertility and yield.

The functional insufficiency of root systems, or even their hypotrophy, is one of the fundamental issues when monitoring the vital and functional prosperity of plants, or even entire communities thereof. A sufficiently developed root system is one of the basic conditions of an optimal trophic state in the relevant plant's organism, and the subsequent development of its tissues, and if applicable its fertility or functional capacity. In close connection with how current climatic excesses, as well as persisting anthropogenic burden, lead to the deterioration of actual vegetative disposition in certain areas, the rooting of plants and woody plants must be supported during the revitalization and rehabilitation of the disrupted areas. Particularly in locations where the rooting process, or eventually also insufficient functional contact by the root system with underground water, creates vegetative problems, the stimulation of root systems by the addition of bio alginates can significantly increase the plant's chances of survival. In the area of the establishment and operation of root water purifiers, the managed strengthening of root systems will bring about a significant increase in their functional effectiveness.

\section{Acknowledgements}

This article was supported by project QJ1520307 entitled "Sustainable Forms of Management in an Anthropogenically Burdened Region." This project was realized with financial support from state budget resources through the KUS program, Ministry of Agriculture of the Czech Republic.

\section{Conflicts of Interest}

The authors declare no conflicts of interest regarding the publication of this paper. 


\section{References}

[1] Gjurov, V. (2005) Company Information Regarding Preparations from the Bio-Algeen Range of the Company Schulze and Hermsen. Klokočná, Mnichovice.

[2] Jurásek, A., Kriegel, H. and Hančl, Z. (1990) New Growth Biostimulators. [New Growth Stimulators]. Forestry Work, 69, 42-43.

[3] Kürzinger, W. (1995) Einsatz von Pflanzenstärkungsmitteln. Kartoffelbau, 46, 418-420.

[4] Reichholf, J. (1999) To Live and Survive in Nature: Ecological Connections. Prague, Ikar.

[5] Dobson, A. (1992) Green Political Thought. Harper Collins, London, 167 p.

[6] Salvato, J.A. (1989) Environmental Engineering and Sanitation. John Willey, New York.

[7] Vostoupal, B., Zajíček, P., Šoch, M., Hrubý, J. and Gjurov, V. (2007) Alginates and Their Utilization in Plant Production. Collection of Lectures from the Conference "Effect of Abiotic and Biotic Stressors on Plant Properties", Plant Production Research Institute, Prague-Ruzyně, 21-22.

[8] Pearce, D. (1996) Economics, and the Challenge of Global Environmental Protection. In: Environmental Economics and Ecological Policy. Litomyšl Seminar Publishing House, Prague, $352 \mathrm{p}$.

[9] Wang, H.Y., Lee, S.S., Tabach, Y. and Cawthon, L. (1982) Biotechnology and Bioengineering Symp., p. 139. Willey, New York.

[10] Vostoupal, B. and Gjurov, V. (2006) Managing the Stimulation of the Development of Root Systems Using Bio-Algeen Preparations. Collection of contributions from the conference Current Findings in Plant Cultivation, Breeding and Protection, National Agricultural and Food Center, Troubsko, Brno, 23-24 November 2006, 73-78.

[11] Vráblíková, J., et al. (1999) Research of Natural Science Environmental Components in the Czech Republic and Slovakia, Ústí nad Labem, Jan Evangelista Purkyně University, $152 \mathrm{p}$.

[12] Vostoupal, B., Šoch, M., Novák, P., Gjurov, V., Jelínek, A., Dědina, M. and Plíva, P. (2005) Possibilities of the Partial Purposeful Redevelopment of the Bioclimate of Rural Settlements Using Preparations from the Bio-Algeen Range. Collection of Contributions from the 20 th Year of a Scientific Conference with International Participation- “Current Bioclimatology Issues... 2005”, Institute of Animal Science Prague, Czech Hydrometeorological Institute Brno, 13 December 2005, 105-108.

[13] Schaeffer, D.J. and Beasley, V.R. (1989) Ecosystem Health. Quantifying and Predicting the Effects of Toxic Chemicals on Ecosystems. Regulatory Toxicology and Pharmacology, 9, 296-311. https://doi.org/10.1016/0273-2300(89)90068-8

[14] Vostoupal, B., Gjurov, V., Novák, P., Šoch, M., Jelínek, A. and Plíva, P. (2006) The Role of Bioalginates in the Process of Controlled Biodegradation during Composting. Collection of Contributions from the Conference "Current Findings in Plant Cultivation, Breeding and Protection, National Agricultural and Food Center Troubsko, Brno, 153-158.

[15] Cholewinski, A. (1998) Wstepna ocena wybranych stymulatorów wzrostu na plony dwóch odmian truskawki w uprawie polowej. Ogólnopolska Nauk. Konfer. Sadownicza, 57-60.

[16] Vostoupal, B., Vurm, V., Vostoupalová, M. and Vurm Jr., V. (1989) Profile Screenplay of the Program of Monitoring the Permeation of Toxins into Important Links 
of Food Chains. Collection of papers from a national conference with international participation- "Methods of Regional Ecological Analyses and Syntheses", KR Czech Association of Scientific and Technical Societies + Regional Ecology Institute of the Czech Academy of Sciences, 1-16.

[17] Kolbe, H. and Blau, B. (1998) Wirkung von Pflanzenstärkungsmitteln auf verschiedene Kultur-arten. Schriftenreihe der Sächsischen Landesanstalt für Landwirtschaft 3, Heft 5, 1-45.

[18] Novák, P., Zabloudil, F., Vráblíková, J. and Šoch, M. (1999) Potential Risks during the Rehabilitation of Agroecosystems. Collection of Contributions "Ecological Forms of Management in the Region", Acta Universitatis Purkynianae, 49, Studia oecologica VII, Faculty of Environmental Science, Jan Evangelista Purkyně University in Ústí nad Labem, 78-87.

[19] Barney, G.O., Blewett, J. and Barney, K.R. (1993) Global 2000. Revisited. Arlington Millen Indy, $268 \mathrm{p}$.

[20] Růžička, J. (1999) Microbiology for Environmental Technology. Brno University of Technology, Brno, 124 p.

[21] Kriegel, H. and Jurásek, A. (1992) Report on the Use of the Biostimulator Bio-Algeen on Forest Woody Plants in Juvenile Stages in the Years 1989-1991. [Report on the Application of the Stimulator Bioalgeen to Young Forest Trees in 1989-1991]. Opočno, Forest and Game Management Research Institute-Research Station. $6 \mathrm{p}$. 